\title{
Timing of Earnings and Capital Structure*
}

\author{
Anton Miglo ${ }^{\dagger}$
}

2016

\section{North American Journal of Economics and Finance, forthcoming}

Abstract. This paper shows that asymmetric information about the timing of earnings can affect capital structure. It sheds new light on the following issues: why profitable firms may be interested in issuing equity and why debt does not necessarily signal a firm's quality. These issues seem to be puzzling from the classical pecking-order theory or signalling theory point of view. The paper also contributes to the analysis of the link between capital structure choice and a firm's expected performance (short-term and long-term). An empirical analysis confirms most of our theoretical results.

*I am grateful to Bram Cadsby, Jean Cossette, Georges Dionne, Claude Fluet, Mike Hoy, Pierre Lasserre, Deborah Lucas, Nicolas Marceau, Vassil Mihov, A. Nejadmalayeri, Thomas Noe, Stephane Pallage, Michel Robe, and Urs Schweizer for usefull suggestions and comments on earlier versions of this paper. Also many thanks to seminar participants at ESADE, 2009 FMA and 2015 EFA annual meetings. The paper is closely related to my PhD thesis at UQAM. I appreciate the financial support of my PhD studies awarded by the SSHRC of Canada and the Institut de finance mathematique de Montreal. I also appreciate the editing assistance and comments of Victor Miglo.

${ }^{\dagger}$ Associate Professor of Finance, Nipissing University, School of Business, North Bay, ON, Canada, e-mail: antonm@nipissingu.ca. 
Keywords: Asymmetric information, Pecking-order theory, Signalling, Timing of earnings

Classification codes: D82, D86, G32

\section{Introduction}

This paper builds on "pecking-order theory" (POT) and signaling theories of capital structure. These theories directly relate to asymmetric information. According to POT (Myers and Majluf, 1984) equity represents an inferior security (firms prefer internal funds and debt). Empirical evidence usually supports one of the main predictions of the POT that there is a negative share price reaction on equity issue announcements. The evidence is mixed about whether firms always follow a pecking order hierarchy $!^{1}$

According to POT, good quality firms have to use internal funds to avoid adverse selection problems and losing value. The signalling theory of capital structure offers models (Ross, 1977; Leland and Pyle, 1978) where good quality firms usually increase leverage to signal quality. Although the empirical evidence finds some support of negative market reaction on leverage-decreasing transactions and a positive reaction on leverage-increasing transactions, in general it does not support a positive market reaction to debt issues. The negative correlation between debt and profitability also contradicts signaling theory. Third, the evidence is mixed regarding the predictions of signaling theory regarding links between capital structure choice/change and future op-

\footnotetext{
${ }^{1}$ For a review of theoretical and empirical literature on POT and signalling theories see, for example, Klein, O’Brien and Peters (2002) and Miglo (2011). For a more recent analysis see, for instance, Komera and Lukose (2015).
} 
erating performance especially with regard to short-term performance. $2^{2}$

The literature analyzing financing-investment games where firm insiders have private information usually deals with situations where firms differ in their qualities or overall intrinsic values. Typically, there are two types of firms: good (high value) and bad (low value). In the present paper, we argue that a situation where a firm has private information about the timing of earnings may generate predictions that are not explained by POT or singalling theory and that also may shed new light on some puzzles including the existence of a signalling equilibrium where firms issue equity. In particular we argue that firms with early exepcted earnings prefer issuing equity as opposed to firm with late earnings. We then test empirically some of our results and find confirmation.

A situation where firms' insiders have private information about the timing of earnings is quite intuitive. For example, firms' major contracts may be public knowledge while their timing and details may only be known to managers. Asymmetric information regarding the timing of earnings may take place because managers often have private information about the choice of inventory and depreciation methods, estimation of pension liabilities, capitalization of leases and marketing expenses, recognition of sales not yet shipped, and delay in maintenance expenditures and delays in production (Miglo, 2007). Pereira and Sousa (2015) noted that it is likely that equity-issuing firms are often involved in earnings management.

Our analysis is related to the asymmetric information literature analyzing situations where firms have equal values (qualities) and private information concerns other parameters. Examples include Giammarino and Neave (1984),

\footnotetext{
${ }^{2}$ See, for example, Jain and Kini (1994), Loughran and Ritter (1997), Mikkelson, Partch and Shah (1997), Pereira and Sousa (2015) and discussions in Miglo (2007, 2011, 2016).
} 
Daniel and Titman (1995), Brick, Frierman and Kim (1998) and Miglo and Zenkevich (2006). Miglo and Zenkevich (2006) argue that if firms differ in the timing of earnings a separating equilirum may exist where some firms issue equity. They noted, however, that the problem of private information regarding the timing of earnings can be mitigated by the up-front equity finanicng that is not considered in their paper ${ }^{3}$ Up-front financing is a part of our model. ${ }^{4}$ Up-front finanicng takes a large portion of equity from existing shareholders magnifying potential moral hazard problems (Jensen and Meckling, 1976). Hence, we include moral hazard considerations in our model as well.

Our article is also related to the literature analyzing capital structure choice under asymmetric information in a dynamic environment (multi-period decision-making situation). Some examples in previous literature include Lucas and McDonald (1990), Viswananth (1992) and Miglo (2007, 2012). Miglo (2007) and Miglo (2012) are the closest models because they consider situations where firms have long-term private information and firm types' order may change over time. However Miglo (2007) only considers a special case where firms with higher value also have higher growth rates and neither artcile considers the case where private information exclusively concerns the timing of earnings.

\footnotetext{
${ }^{3}$ This argument is stronger when interest rates are lower. In recent years, for example, we observe a histroically low (sometimes even negative) interest rate environment. In this case the difference between the values of firms that have different timings of earnings (same amounts) is negligeable and up-front financing can completely eliminate an asymmetric information problem about the timing of earnings.

${ }^{4}$ Exisitng literature focuses on the following differences between up-front and staged financing: advantages of staged financing in mitigating moral hazard issues in venture financing (Neher, 1999); regulation requirements (Hart, 2009); impact on taxes (Mercer-Blackman, 2008). Our paper adds an asymmetric information aspect to this list.
} 
The summary of our main results is as follows. First, we confirm the intuition described previously that if information about the timing of earnings is asymmetric, but no moral hazard is involved, an equilibrium is one where all firms use up-front equity finanicng and the fractions of equity are negotiated with investors initially regardless of the timing of future earnings. When both asymmetric inofrmation and moral hazard are present, multiple equilibria may exist. We find that up-front finanicing and long-term debt are never part of efficient separating equilibria. We show that the only efficient separating equilibrium is one where a firm with late earnings issues short-term debt and a firm with early earnings issues equity. This equilibrium implies that the debt/equity ratio is negatively correlated with firm's short-term earnings and positively correalted with long-term earnings. Similarly it predicts that firms issuing equity have higher earnings soon after the issue and lower long-term earnings compared to non-issuing firms. These firms also have lower operating performance in the long run. Leverage is negatively correlated with profitability because firms with higher profits in the first period issue equity in the first period. Firms with a low rate of earnings growth issue equity and firms with a high rate of earnings growth issue debt (Mohamed and Eldomiaty, 2008; and Chichti and Bougatef, 2010).

We also test out model using a sample of 501 firms listed on NYSE, NASDAQ and TSX and their capital structure choice in 2010. We find that the debt/equity ratio is negatively correlated with short-term earnings and positively correlated with long term earnings, which is one of our main results.

The rest of this paper is organized as follows. The next section describes the basic model and presents some preliminary theoretical results. Section 3 analyses the case with asymmetric information and moral hazard and contains major results. It also discusses the model's implications. Section 4 discusses 
model extensions and robustness. Section 5 reports the results of empirical analysis and the conclusion is drawn in Section 6.

\section{Model description and some preliminaries}

Consider a firm with a two-stage investment project. The model's description follows the footsteps of Miglo and Zenkevich (2006) with a major addition of moral hazard in consideration and some other changes such as a wider range of possible financing strategies for firms. The firm's objective is to maximize the wealth of initial shareholders (founders), whom we will call the entrepreneur. In each stage $t=1,2$ an amount $b$ has to be invested. In each stage, the project can either be successful or unsuccessful. If the former is the case, the cash flow, $r_{t}$, equals 1 and if the latter is the case, the cash flow equals 0 . The firm's initial capital structure is $100 \%$ equity, with $n$ shares outstanding. Let $\alpha_{t}$ denote the proportion of equity owned by the entrepreneur in period $t$ (immediately after the issue of securities in period $t$, if it takes place).

In each period, the firm's success depends on the entrepreneur's effort in that period, and the firm's intrinsic quality in that period. Regardless the level of the entrepreneur's effort, some firms have better short-term earnings potential and some firms have better long-term earnings potential. The entrepreneur's effort is $z_{j t}$. $z_{j t} \in\{0,1\}$, where $j$ denotes the firm's type, $j \in\{l, s\}$. If $z_{j t}=0$, the probability of success for either firm in period $t$ equals 0 and the entrepreneur gets a private benefit equal to $c:^{5}$ If $z_{j t}=1$, the probability of success in period $t$ equals $\rho_{j t}$. Without loss of generality we assume

\footnotetext{
${ }^{5}$ This way of modelling the cost of effort is chosen for simplicity. Alternatively, one can assume that there is some cost to the entrepreneur when providing a high level of effort. Qualitatively, the results will be similar.
} 
$\rho_{j 1}+\rho_{j 2}=1$. This implies that if the entrepreneur delivers a high level of effort in both periods, the expected total earnings over the two periods are the same (equal to unity) for both firm types and they differ only in their timing of expected performances. Further we denote $\theta_{j}$ the probability of success in period 1 for type $j$ (the probability of success in period 2 is then $1-\theta_{j}$ ). We assume $\theta_{l}<\theta_{s}$. It implies that $s$ (stands for "short-term") has better expected performance in period 1 and $l$ (stands for "long-term") has better expected performance in period 2 .

We assume $b<1 / 2$ with the $\theta$ 's restricted to the interval $[b, 1-b]$, which implies that, conditional on the entrepreneur's high level of effort, the investment has non-negative net-present value (NPV) in each period, i. e. the expected earnings are at least equal to the amount of investment in period one $(b \leq \theta)$ and in period two $(b \leq 1-\theta)$. Also we assume

$$
2 b>\max \{\theta, 1-\theta\}
$$

implying that the earnings from only one stage are not sufficient to cover the cost of investment in both stages. If the entrepreneur fails to obtain financing, his payoff equals 0. If financing is obtained and the entrepreneur delivers a low level of effort in period $t$, the NPV of all benefits and costs in stage $t$ is $c-b$. If $z_{j 1}=1$, the NPV of stage 1 is $\theta_{j}-b$ and if $z_{j 2}=1$, the NPV of stage 2 is $1-\theta_{j}-b$. We thus assume

$$
c<\min \{\theta, 1-\theta\}
$$

This guaranties that a high level of effort is socially optimal in both periods.

The entrepreneur's choice of effort and private benefits are non-observable and non-verifiable. Investors make decisions about providing financing for the firm taking into account their beliefs about the firm's type and their expectations about the entrepreneur's level of effort. The firm's profit and it's 
capital structure choice are observable and verifiable. There exists universal risk-neutrality in this economy. In addition, the competition among the investors is perfect. This implies zero market profit and risk-neutral valuation of any security issued. Finally, note that given that the high level of effort is socially optimal, the firm's first-best value (expected earnings minus investment cost) equals the sum of the project's NPVs in stage 1 and 2 or $\theta_{j}-b+1-\theta_{j}-b=1-2 b$.

\subsection{Financing strategies}

The firm may use either stage or up-front financing, and in both cases it can use either equity or debt.

Equity financing. In the case of up-front equity financing (denote this strategy by $u$ ), the firm issues equity in the amount of $2 b$ in the first period. The firm invests $b$ immediately and keeps $b$ for the second period. Alternatively, the firm may issue an amount of equity equal to $b$ (denote this strategy by e). Hence, in the second period, the firm has a choice between internal financing (the amount of internal financing is denoted by $f$ ) and external financing that is assumed to be debt financing (the amount of second-period debt equals $b-f$ ). The internal financing in period 2 (retained earnings) will only be available if earnings are generated in period 1 and are not distributed as dividends 6

Short-term debt $(d)$. In this case, the firm gets an amount $b$ from the market by issuing short-term debt. If $d$ was chosen and the firm's profit is not

\footnotetext{
${ }^{6}$ The introduction of the possibility of other types of external financing in the second period will change nothing in the model's main results. It will be shown that in the case of a signalling equilibrium the value of any security issued in the second period relies heavily on the firm's expected performance in the second period, which is the key in our main results.
} 
sufficient to repay the debt (profit equals 0) then there are two possibilities. First, the firm may be declared bankrupt. In this case, the shareholders get nothing and the creditors receive the liquidation value $V_{L}=\lambda\left(E r_{2}-b\right)$, where $0 \leq \lambda \leq 1$. This equation shows that the liquidation value is proportional to the expected profit from the second stage of the project. For instance, if $\lambda$ is low, the cost of bankruptcy is high, and the liquidation value is low. Alternatively, the firm can continue to operate. This decision (to continue or to liquidate) is the result of a renegotiation between the entrepreneur and the creditors (Giammarino, 1989). The renegotiation is conducted in the following manner: the entrepreneur makes a "take-it-or-leave-it" offer to the creditors; the creditors may accept or reject the offer; if the creditors accept the continuation they get a fraction of the firm's equity; if the offer is rejected the firm is liquidated. Note that up-front financing cannot be used with short-term debt: it makes no sense for the shareholders to keep cash in the presence of senior claims in the following period. Although there are other ways of modelling different kinds of financing we believe that those suggested in the paper are very general and more importantly the results about the pricing of securities are very intuitive. We discuss some other extensions in Section 6.

Long-term debt $(k)$. The investment has two stages in our model so we assume that financing with long-term debt is up-front and the firm cannot distribute first-period cash to the shareholders (dividend covenants). This allows the firm to avoid the debt overhang problem in the second period when internal funds are not sufficient to cover the second-period investment and the firm has difficulty raising second-period financing in the presence of long-term claims. Alternative methods of long-term debt financing and their implications in a similar environment are discussed in Miglo (2007).

The sequence of events is illustrated in figure 1. We assume that the firm's 
type is revealed to the entrepreneur in period 0 while financing, investment, and production take place in periods 1 and 2. First-period outside shareholders (strategies $e$ and $u$ ) discover the firm's type immediately after acquiring shares. Since the stages are technologically dependant, if the entrepreneur is unable to obtain first-period financing there is no investment in either period and the entrepreneur's utility equals 0.7

\begin{tabular}{|c|c|c|}
\hline$t=0$ & $t=1$ & $t=2$ \\
\hline $\begin{array}{l}\text { Firm's type } \\
\text { is revealed to } \\
\text { the entrepreneur }\end{array}$ & $\begin{array}{l}\text { Entrepreneur chooses } \\
d, e, k \text { or } u \\
\text { Entrepreneur chooses } z_{1} \\
\text { Investment yields } r_{1} \\
\text { If } d \text { was played and } r_{1}=1 \\
\text { the creditors are paid } \\
\text { Shareholders determines } \\
\text { first-period dividends } \\
\text { If } d \text { was played and } r_{1}=0 \\
\text { the entrepreneur } \\
\text { determines } \lambda \\
\text { If the creditors reject the } \\
\text { offer, the firm is liquidated } \\
\text { and the creditors get } V_{L}\end{array}$ & $\begin{array}{l}\text { If external financing } \\
\text { is needed, the entrepreneur } \\
\text { issues second-period debt } \\
\text { The entrepreneur chooses } z_{2} \\
\text { Investment yields } r_{2} \\
\text { It is distributed } \\
\text { to the claimholders }\end{array}$ \\
\hline
\end{tabular}

Figure 1. The sequence of events.

\subsection{Asymmetric information without moral hazard}

Consider the situation with asymmetric information about the firm's type but without moral hazard, i.e. let us assume that the entrepreneur always delivers

\footnotetext{
${ }^{7}$ Throughout the article we use the concept of Perfect-Bayesian equilibria. In some cases, a complete description of off-equilibrium investors beliefs about the firm type can be ommitted for brevity. They are avilable upon request.
} 
a high level of effort.

Proposition 1. If there is no moral hazard, strategy $u$ is a first-best pooling equilibrium.

Proof. Consider the situation where both firm types play $u$, i.e. raise an amount $2 b$ by issuing shares in period 1 , invest an amount $b$ immediately and keep the second half (also $b$ ) for investments in period 2. Also, if a firm deviates from this strategy and uses external financing for stage 2, the market believes that the firm is $s$. First-period outside investors get a fraction $1-\alpha_{1}$ of the firm shares. Their expected payoff is $\left(1-\alpha_{1}\right) E\left(r_{1}+r_{2}\right)=1-\alpha_{1}$ since total expected earnings equal 1. It should be equal to the amount of their investment $2 b$. Hence, $1-\alpha_{1}=2 b$ and $\alpha_{1}=1-2 b$. This means that the entrepreneur's expected payoff for each firm is $\alpha_{1} E\left(r_{1}+r_{2}\right)=1-2 b$. This is equal to the first-best firm value for the entrepreneur, as was mentioned previously. If $l$ deviates and borrows in the second period it suffers from the fact that it will be perceived by the market as type $s{ }^{8}$ Type $s$ is indifferent between internal financing and borrowing in the second period because the interest rate would correspond to type $s$ according to the market beliefs described above. This situation constitutes an equilibrium. End Proof.

The idea behind this proposition was discussed in the introduction. In an environment without moral hazard, total earnings are the same for all firm types: this completely eliminates the problem of asymmetric information under up-front financing. $l$ has high expected earnings in period 2 but it can finance the second stage of the project internally using the remains of initial

\footnotetext{
${ }^{8} s$ has lower expected earnings in period 2 than $l$. Therefore, the value of securities is lower in period 2 if the firm is perceived as type $s$ comparing to the case when the firm is perceived as type $l$. For price calculations, see Appendix 4.
} 
financing, thereby avoiding the lemon problem. $9^{9}$ If $s$ attempts to borrow in the second period the market will correctly realize the firm's type, effectively eliminating it's ability to earn informational rents in this period.

\section{$3 \quad$ Asymmetric information with moral hazard}

In this case, the valuation of securities issued by the firm is based on the market's belief about the entrepreneur's effort. If investors believe the entrepreneur's level of effort will be low, they will either reduce the share price, increase the interest rate charged, or refuse to finance the project. The investors' beliefs are based on their calculation of the entrepreneur's incentives. Therefore, the choice of financing should send a credible signal to the market. However, agency costs will arise under any type of financing. Under equity financing, agency costs arise because the entrepreneur's fraction of equity is reduced, decreasing the incentive to provide high effort. Under short-term debt financing, agency costs arise when default occurs in the first period and creditors obtain a high fraction of equity, reducing the incentive for entrepreneurial effort in the second period. Agency costs may also arise if the face value of debt is excessively high, leading the entrepreneur to provide a low level of effort in the first period. Similarly, under long-term debt financing the problem may appear when first-period earnings are low, and the entrepreneur's payoff for a high level of effort in the second period is diluted by the creditors' claims.

\footnotetext{
${ }^{9}$ We use the term "lemon" to describe a situation where private information leads to the underpricing of a "good" type. See Akerloff (1970) for a classical example.
} 


\subsection{Preliminary results}

In order to find an equilibrium in the model with both asymmetric information and moral hazard we will first establish some preliminary results. We know from the previous section that $u$ is optimal financing under asymmetric information without moral hazard. With moral hazard the entrepreneur's effort depends on private benefits from a low level of effort. If these benefits are small, the low level of effort will be chosen and vice versa. The following lemma shows the conditions under which $u$ is the first-best financing (i. e. the entrepreneur's level of effort is high in both periods) when information about the firm's type is symmetric.

Lemma 1. When information about the firm's type is symmetric, the entrepreneur's level of effort is high in both periods under strategy $u$ if and only if

$$
\theta \leq 1 / 2 \text { and }(1-2 b) \theta \geq c
$$

or

$$
\theta>1 / 2 \text { and }(1-2 b)(1-\theta) \geq c
$$

Proof. See Appendix 1

Proposition 1 and Lemma 1 imply that when both asymmetric information and moral hazard are present, a first-best equilibrium can exist if the cost of low level of effort is sufficiently high, or the private benefits from a low level of effort are small. Comparing conditions (3) and (4) for each type leads us to the following proposition:

Proposition 2. Strategy $u$ is a first-best pooling equilibrium if and only if: 1) $\theta_{l}>1 / 2$ and $c \leq(1-2 b)\left(1-\theta_{s}\right)$; 2) $\theta_{l} \leq 1 / 2<\theta_{s}$ and $c \leq \min \{(1-$ $\left.2 b)\left(1-\theta_{s}\right),(1-2 b) \theta_{l}\right\}$; and 3) $\theta_{s} \leq 1 / 2$ and $c \leq(1-2 b) \theta_{l}$.

Proof. See Appendix 2. 
Next we consider situations where the equilibrium described in Proposition 2 does not exist. These are:

$$
\begin{gathered}
\theta_{l}>1 / 2 \text { and } c>(1-2 b)\left(1-\theta_{s}\right) \\
\theta_{l}<1 / 2<\theta_{s} \text { and } c>\min \left\{(1-2 b)\left(1-\theta_{s}\right),(1-2 b) \theta_{l}\right\} \\
\theta_{s}<1 / 2 \text { and } c>(1-2 b) \theta_{l}
\end{gathered}
$$

\subsection{Efficient separating equilibria}

An equilibrium is efficient if financing is obtained for both stages, the entrepreneur's level of effort is high in both periods (respecteively, the incentive constraints should hold for both firm types in each period) and his expected payoff equals $1-2 b$.

The general intuition concerning the role of asymmetric information in our model is as follows. The prices of securities can be affected by the "lemon" effect in both periods. Intuitively, $l$ would seem to have an informational advantage in the first period: lower profits in this period mean that this type of firm can capitalize on the adverse selection problem. On the other hand, in the second period, the informational advantage passes to $s$. If $l$ were to issue equity in the first period, it would always be mimicked by s. $s$ stands to gain in the second period by being perceived as a firm with high profits in the second period 10

To signal its type, $l$ can issue short-term debt. In particular, if the cost of bankruptcy is high enough (or when non-recourse debt is issued), first-period

\footnotetext{
${ }^{10}$ For more discussion regarding this observation see Miglo and Zenkevich (2006) and Miglo (2007).
} 
interest rates will be relatively high compared to second period rates, since $l$ is considered "bad" in the first period and "good" in the second. Given such an interest rate profile, we show that if $s$ issues short-term debt, it will be beneficial to creditors, but not to the firm. This is because creditors benefit in the first period due to high interest rates and the fact that $s$ does well in that period.

The analysis below develops the above ideas but first we argue that $u$ is never played in an efficient signaling equilibrium. Recall that in an environment without moral hazard, up-front equity is a good strategy because it can mitigate problems related to asymmetric information about the timing of earnings (Proposition 1). The result holds when there is moral hazard but its extent is relatively small (Proposition 2). If pooling with $u$ is not an equilibrium described in Proposition 2, the private benefits from a low level of effort are relatively high for at least one firm type (conditions (5)-(7)). Even if for one firm type private benefits are low and it can use $u$, these benefits will be high for the other firm type (which does not play $u$ in equilibrium). Therefore, that type will mimic the other type by playing $u$. Since the first-period share price is always $\frac{1-2 b}{n}$ (type-independent), it will not suffer from the adverse selection problem, but will gain by providing a low level of effort.

Lemma 2. When information between the firm and the market is symmetric, the share price under strategy e or $u$ equals $\frac{1-2 b}{n}$.

Proof. See Appendix 3.11

Proposition 3. $u$ is never played in an efficient signalling equilibrium.

Proof. See Appendix 4.

\footnotetext{
${ }^{11}$ For similar results and discussions of the intuition behind it see, for example, Miglo and Zenkevich (2006) and Miglo (2007). Our result is more general because it takes the possiblity of up-front financing into consideration as well.
} 
Proposition 3 is consistent with Neher (1999). This paper argues that upfront financing is less important (stage financing is more important) when the entrepreneurial moral hazard problem becomes more important. The author also discusses empirical evidence consistent with this prediction.

Let us analyze other strategies. Let $V_{x}(\theta, \widehat{\theta})$ be the entrepreneur's final payoff if strategy $x$ is played, the firm is of type $\theta$ but is perceived as type $\widehat{\theta}$, given a high level of effort in both periods.

Lemma 3. $V_{e}\left(\theta_{s}, \theta_{l}\right)>1-2 b$ and $V_{e}\left(\theta_{l}, \theta_{s}\right)<1-2 b$.

Proof. See Appendix 5.

The idea behind Lemma 3 is that when the level of effort is high in both periods, the first-period share price is type-independent as follows from Lemma 2. Because the first-best share price in period 1 is the same for all types, $s$ benefits from its informational advantage in the second period (when it is really a "lemon"). This implies that an efficient separating equilibrium where $l$ plays $e$ does not exist.

Proposition 4. An efficient separating equilibrium where l plays e does not exist.

Proof. Suppose the opposite is true: that such and equilibrium exists. By Lemma 3 , the payoff to $s$ if it mimics $l$ is greater than $1-2 b$ because $\theta_{s}>\theta_{l}$. End proof.

Now consider strategy $k$. The difficulty involved in $l$ separating itself by playing $k$ is similar to the case of strategy $e$. Since the value of long-term debt depends on the firm's performance in both periods and the values of both types (under high level of effort in both periods) are equal, then intuitively, $l$ does not have an advantage when issuing long-term debt.

Proposition 5. An efficient separating equilibrium where $l$ plays $k$ does not exist. 
Proof. See Appendix 6.

Let us turn to strategy $d$.

Lemma 4. When information between the firm and the market is symmetric, the debt face value under strategy d equals: $D=\frac{b-\lambda(1-\theta)(1-\theta-b)}{\theta}$.

Proof. See Appendix 7.

This result means that the face value of debt is lower when the probability of success in period $1(\theta)$ is higher or when the bankruptcy costs are low (high $\lambda$ ) among other things.

Proposition 6. The set of parameters for which $V_{d}\left(\theta_{s}, \theta_{l}\right)<1-2 b$ is not empty.

Proof. The following is an example proving the proposition: $\lambda=0$ and $\theta_{l}<1 / 2$. First note that when $s$ mimics $l$ it will never use internal financing in the second period because the second-period interest rates for type $l$ are advantageous given the high performance of this type in the second period. Therefore, when $s$ mimicks $l$, it borrows $b$ in period 2 and its payoff over two periods can be written as

$$
V_{d}\left(\theta_{s}, \theta_{l}\right)=\theta_{s}\left(1-\frac{b}{\theta_{l}}\right)+\left(1-\theta_{s}\right)\left(1-\frac{b}{1-\theta_{l}}\right)
$$

This means that the probability that $r_{1}=1$ equals $\theta_{s}$. Since the firm is perceived as type $l$, the debt face value is $\frac{b}{\theta_{l}}$ (Lemma 4). Hence, the entrepreneur's first-period expected earnings are $\theta_{s}\left(1-\frac{b}{\theta_{l}}\right)$. The reasonning is similar in period 2.

From (8) we have:

$$
V_{d}\left(\theta_{s}, \theta_{l}\right)<1-2 b \Leftrightarrow \frac{\theta_{s}}{\theta_{l}}+\frac{1-\theta_{s}}{1-\theta_{l}}>2 \Leftrightarrow
$$




$$
\Phi\left(\theta_{l}\right) \equiv \theta_{s}\left(1-\theta_{l}\right)+\left(1-\theta_{s}\right) \theta_{l}-2 \theta_{l}\left(1-\theta_{l}\right)>0
$$

where $\Phi$ is convex with roots $\theta_{l}=1 / 2$ and $\theta_{l}=\theta_{s}$. Therefore $V_{d}\left(\theta_{s}, \theta_{l}\right)<1 / 2$ if $\theta_{l}<1 / 2$. [Note that since 10 is strictly positive, Proposition 5 may hold when $\lambda>0$ ( $\lambda$ is sufficiently small) by continuity] End proof.

A downward sloping interest rate profile $\left(\theta_{l}<1 / 2\right)$ is suitable for performanceimproving firms and not for firms with a lower rate of profit growth $\left(\theta_{s}>\theta_{l}\right)$, which are better off with upward sloping interest rate profile.

Corollary 1. The only efficient separating equilibrium, where both debt and equity are issued, is one where $l$ plays $d$ and $s$ plays $e$.

Proof. It follows from Propositions 3-6 that the only candidate for an efficient separating equilibrium is one where $l$ plays $d$ and $s$ plays $e$. An example is the situation where $\lambda$ is sufficiently small or equal $0, \theta_{l}<1 / 2<\theta_{s}$ and $c>\min \left\{(1-2 b)\left(1-\theta_{s}\right),(1-2 b) \theta_{l}\right\}$. In this case, a first-best pooling equilibrium with $u$ does not exist as follows from (6). Also in this case $l$ does not mimick $s$ by Lemma 3 and $s$ does not mimick $l$ as follows from the proof of Proposition 5. End proof.

Finally note that inefficient equilibria are discussed in Appendix 8.

\subsection{The model's implications}

Our model has several theoretical and empirical implications.

(i) Timing of earnings may affect capital structure choice. This paper develops the idea from Miglo and Zenkevich (2006) that the timing of earnings may affect the firm's capital structure choice.

(ii) Asymmetric information and moral hazard are both important when considering links between the timing of earnings and capital structure choice. 
We show that the problem of asymmetric information about the timing of earnings (Miglo and Zenkevich, 2006) can be fully solved by using up-front equity finanicng. We included moral hazard issues into consideration and obtain several results (Proposition 1, 2 and Corollary 1) that describe equilibria under different situations.

(iii) Debt-equity ratio is negatively correlated with short-term earnings and positively correlated with long-term earnings. This result is probably the model's main empirical prediction. It is based on the equilibrium described in Corollary 1 and it also holds in 2 of the 3 equilibria from Proposition 7. Note that the result about short-term earnings is of particular interest since it has not been the main focus of existing empirical research.

(iv) Debt-equity ratio is positively correlated with the rate of earnings growth (long-term vs. short-term). Note that some recent papers found that firms with a low rate of earnings growth issue equity and firms with high rate of earnings growth issue debt (Mohamed and Eldomiaty, 2008; and Chichti and Bougatef, 2010).

\section{The model extensions and robustness}

Mixed financing. The main results of the model are robust when the possibility of mixed financing is allowed. The main insight that firms with an increasing profit profile are at a disadvantage when issuing equity while stagnating firms can "hide" their low second-period performance by issuing equity (the price of which is type irrelevant), holds under mixed financing. We can show that if an equilibrium exists where firms with higher second-period performance issue more equity, then there also exists a separating equilibrium where these firms issue less equity, but not vice versa. Thus, the latter equilibrium prevails (see 
analogous reasoning in Goswami, Noe and Rebello, 1995).

Different profit distribution functions. Now we briefly comment on the model's robustness with respect to possible generalizations of projects' profit distribution functions ${ }^{12}$ For example, one can consider situation where firm profits are ordered by first-order dominance. One can show that the basic results such as propositions 1, 3, 4 and 5 and lemmas 2 and 3 hold. This provides an idea about why firms with "late" earnings avoid issuing equity. However, since $V_{d}$ becomes non-linear, the determination of exact conditions for the existence of different types of equilibrium, especially for the case of multiple type economy become very difficult technically. Nevertheless, numerical calculations for some classes of distribution functions confirm the results found in this paper.

The distribution of types. Our analysis shows that the results may hold even in a multiple types environment although more research is required ${ }^{13}$ Consider the case where all firms have the same total value and only differ in the timing of their earnings. Let the distribution of types be a truncated exponential distribution: $f(\theta)=K \exp (-\gamma \theta){ }^{14}$ where $\theta$ is the expected profit in the first period. Let $y$ be the average first-period earnings in the economy. High $y$ corresponds to a stagnating economy (low second-period profit) and a low $y$ indicates a growing economy. Theoretically possible equilibria are: semi-separating, pooling with debt or pooling with equity. If the equilibrium is semi-separating, firms with $\theta<\theta^{*}$ issue debt and firms with $\theta>\theta^{*}$ issue equity. This equilibrium is consistent with our results since it implies that the

\footnotetext{
${ }^{12}$ Recall that we use the Bernoulli function in the model.

${ }^{13}$ It is wellknown that calculations become singificantly more complicated in that case.

${ }^{14}$ Where $K=\frac{\gamma}{e^{-\gamma b}-e^{-\gamma(1-b)}} . K$ is a constant that allows us to keep the cumulative probability equal to 1 .
} 
average first-period performance of firms issuing equity is higher that that of non-issuing firms. The results of numerical analysis are presented in the Table below.

\section{Table 1. Equilibrium with multiple types.}

The density of types is $f(\theta)=K \exp (-\gamma \theta)$ where $\theta$ is the expected profit in the first period. $y$ is the average first-period profit in the economy. High $y$ corresponds to a stagnating economy (low second period profit) and a low $y$ indicates a growing economy. Theoretically possible equilibria are: semi-separating, pooling with debt or pooling with equity. If several equilibria exist, the one with minimal mispricing is chosen. If the equilibrium is semi-separating, firms with $\theta<\theta^{*}$ issue debt and firms with $\theta>\theta^{*}$ issue equity.

a) $b=0.4$

\begin{tabular}{|c|c|c|c|c|c|c|c|c|}
\hline$\gamma$ & $<0$ & 0 & 2 & 4 & 6 & 8 & 10 & 20 \\
\hline$y$ & $>0.5$ & 0.5000 & 0.4934 & 0.4868 & 0.4805 & 0.4744 & 0.4687 & 0.4463 \\
\hline $\begin{array}{l}(1-y) / y \text {, econ- } \\
\text { omy rate of } \\
\text { growth }\end{array}$ & $<1$ & 1.0000 & 1.0270 & 1.0542 & 1.0813 & 1.1079 & 1.1336 & 1.2408 \\
\hline equilibrium type & $\begin{array}{l}\text { pooling with } \\
\text { debt }\end{array}$ & \multicolumn{7}{|c|}{ separating } \\
\hline$\theta^{*}$ & - & 0.5999 & 0.5594 & 0.5396 & 0.5297 & 0.5198 & 0.5099 & 0.4703 \\
\hline $\begin{array}{l}1-F\left(\theta^{*}\right) \text {, pro- } \\
\text { portion of firms, } \\
\text { issuing equity }\end{array}$ & 0.0 & 0.0005 & 0.1720 & 0.2230 & 0.2262 & 0.2276 & 0.2288 & 0.2310 \\
\hline
\end{tabular}

b) $b=0.25$ 


\begin{tabular}{||l|l|c|c|c|c|c|c|c||}
\hline \hline$\gamma$ & $<0$ & 0 & 2 & 4 & 6 & 8 & 10 & 20 \\
\hline$y$ & $>0.5$ & 0.5000 & 0.4590 & 0.4217 & 0.3905 & 0.3657 & 0.3466 & 0.3000 \\
\hline $\begin{array}{l}(1-y) / y, \text { econ- } \\
\text { omy rate of } \\
\text { growth }\end{array}$ & $<1$ & 1.0000 & 1.1786 & 1.3711 & 1.5610 & 1.7347 & 1.8851 & 2.3336 \\
\hline $\begin{array}{l}\text { equilibrium type } \\
\text { pooling with } \\
\text { debt }\end{array}$ & - & & & & & & \\
\hline$\theta^{*}$ & 0.7499 & 0.5750 & 0.4875 & 0.4250 & 0.3750 & 0.3376 & 0.2876 \\
\hline $\begin{array}{l}1-F\left(\theta^{*}\right), \text { pro- } \\
\text { portion of firms, } \\
\text { issuing equity }\end{array}$ & 0.0 & 0.0002 & 0.2439 & 0.2907 & 0.3158 & 0.3559 & 0.4126 & 0.4715 \\
\hline \hline
\end{tabular}

\section{Empirical analysis}

\subsection{Data and Summary Statistics}

A sample of companies listed on NYSE, NASDAQ and TSX was taken and data about their capital structure choices in 2010 and subsequent performances is obtained from Bloomberg markets, Yahoo finance, Google finance and the companies' websites 15 The data provides information about balance sheet, income statement and operating performance data and about the market prices of securities issued by the firms. The initial sample contained more than 4000 firms. The final sample contains a total of 473 firms. Table 2 displays the number of firms by the value of assets groups as well as some summary statistics. In order to match the analysis with our model (firms have positive NPVs), firms with negative earnings in 2011, 2012, 2013 were excluded as well

\footnotetext{
${ }^{15}$ https://finance.yahoo.com/, http://www.google.ca/finance, http://www.bloomberg.com/markets etc.
} 
as firms with negative equity issues (reduced number of shares outstanding) or negative net debt change.

\subsection{Capital Structure and Firms' Earnings}

The key prediction of our model is that firms will have a higher fraction of equity in their capital structure when they expect higher short-term earnings and lower long-term earnings. To measure a firm's earnings, we use EBIT (earnings before interest and taxes) as opposed to net earnings, which is consistent with the spirit of our model. Table 3 presents the means of the performance measures. In calculating the percent changes, we exclude the firms that have negative or zero starting values since their results are meaningless.

We use 2011 earnings or the sum of the 2011 and 2012 earnings for shortterm earnings. Our model has two periods (stages). So to stay in the spirit of our model, market capitalization in 2012 or in 2013 is used as an apprximation of the value of long-term earnings (the "second stage" has no time limit for real firms). We define capital structure as the debt ratio (ratio of debt over total assets). To test our prediction, we run the following regression:

$$
\begin{aligned}
\text { DebtRatio }_{2010}= & \alpha+\beta_{1} * \text { STEarnings }+\beta_{2} * \text { LTEarnings }+\beta_{3} * \text { Asset }_{2010}+ \\
& \beta_{4} * \text { FARatio } \text { ER }_{2010}+\beta_{5} * \text { Tax Rate }_{2010}+\beta_{6} * \text { Cash }_{2010}+\varepsilon
\end{aligned}
$$

where the dependent variable is the debt ratio in 2010. The independent variables include short-term earnings (STEarnings) and long-term earnings (LTEarnings). STEarnings are EBIT in 2011 measured in percent to EBIT in 2010. LT Earnings is the market capitalization in 2012 measured in percent to the market capitalization in 2010. We also run a similar regression where 
STEarnings is the average of the earnings in 2011 and 2012 and LTEarnings is the market capitalization in 2013. The control variables include the company size, which is the value of assets, the fixed assets ratio (fixed assets over assets), the effective tax rate and the amount of cash. The fixed assets ratio and the effective tax rate are used to capture the effect of trade-off theory (tax shield and bankruptcy costs) and cash is used to measure the extent of moral hazard issues (the "empire-building risk" etc.).

The correlation coefficients and the OLS regression results are reported respectively in Table 4 and Table 5 . The results show that the debt ratio is negatively associated with short-term earnings and positively associated with long-term earnings. The positive association with fixed assets is consistent with the notion that firms with smaller bankruptcy costs are more leveraged. The negative correlation with the efficient tax rate is consistent with the negative correlation between debt and profitability, i.e. more profitable firms have higher tax rates and smaller leverage. The positive association with the amount of cash is consistent with the agency cost of debt theory (debt and discipline idea etc.) in that firms with larger risk of moral hazard problems should have higher debt.

STEarnings are singificantly negatively correlated with the debt ratio. LTEarnings are significantly and positively correlated with the debt ratio. This result implies that firms will raise more equity when the short-term earnings are stronger. This result is consistent with the prediction of our model.

\section{Table 2}

\section{Sample and Summary Statistics}

This table presents the sample and summary statistics of firms. Assets are in 000000s dollars. FARatio is Fixed Assets/Assets. Cash is in 000000s. The columns Debt/Assets, FARatio, TaxRate and Cash show the average value of parameters within firms groups in 


\begin{tabular}{|l|l|l|l|l|l|}
\hline Assets & $\begin{array}{l}\text { Number of } \\
\text { Firms }\end{array}$ & Debt/Assets & FARatio & TaxRate & Cash \\
\hline $0-100000$ & 47 & 0.3278 & 0.1165 & 0.2263 & 7.8480 \\
\hline $100000-$ & 138 & 0.3071 & 0.1841 & 0.2580 & 51.2444 \\
1000000 & & & & & \\
\hline $1000000-$ & 159 & 0.2779 & 0.2892 & 0.2517 & 257.6564 \\
\hline 5000000 & & & & & \\
\hline $5000000-$ & 41 & 0.2735 & 0.2926 & 0.2704 & 459.1837 \\
10000000 & & & & & \\
\hline $10000000-$ & 73 & 0.2604 & 0.3419 & 0.2629 & $2,089.0679$ \\
\hline 50000000 & & & & & $10,622.6508$ \\
\hline $50000000-$ & 15 & 0.2092 & 0.2275 & 0.2701 & \\
\hline Total & 473 & & & & \\
\hline
\end{tabular}

\section{Table 3}

\section{Firms' Performance 2011-2013}

EBIT and Market Capitalization are measured in dollar 000000s. The table shows the average value of parameters within firms groups. EBIT $(11,12)$ is the average of earnings in 2011 and 2012. EBIT $(2011, \%)$ is the ratio EBIT (2011)/EBIT (2010). EBIT (11,12,\%) is the ratio EBIT (11,12)/EBIT (2010). MCap (2012) and MCap (2013) are the market capitalizations in 2012 and 2013. MCap (2012,\%) is the ratio MCap (2012)/MCap (2010). MCap (2013,\%) is the ratio MCap (2013)/MCap (2010). In calculating the percentage changes (growth rates), observations with negative or zero starting values are excluded. 


\begin{tabular}{|c|c|c|c|c|c|c|c|c|}
\hline $\begin{array}{l}\text { Assets } \\
(2010)\end{array}$ & $\begin{array}{l}\text { EBIT } \\
(2011)\end{array}$ & $\begin{array}{l}\text { EBIT } \\
(11,12)\end{array}$ & $\begin{array}{l}\text { EBIT } \\
(2011, \%)\end{array}$ & $\begin{array}{l}\text { EBIT } \\
(11,12, \%)\end{array}$ & $\begin{array}{l}\text { MCap } \\
(2012)\end{array}$ & $\begin{array}{l}\text { MCap } \\
(2013)\end{array}$ & $\begin{array}{l}\text { MCap } \\
(2012, \%)\end{array}$ & $\begin{array}{l}\text { MCap } \\
(2013, \%)\end{array}$ \\
\hline $0-100000$ & 9.2 & 19.2 & 1.53 & 1.67 & 38.2 & 44.6 & 2.41 & 2.07 \\
\hline $\begin{array}{l}100000- \\
1000000\end{array}$ & 46.7 & 99.9 & 1.56 & 1.96 & 408.3 & 467.3 & 1.36 & 1.64 \\
\hline $\begin{array}{l}1000000- \\
5000000\end{array}$ & 218.7 & 475.9 & 1.03 & 1.18 & $2,188.2$ & $2,435.4$ & 1.31 & 1.50 \\
\hline $\begin{array}{l}5000000- \\
10000000\end{array}$ & 581.1 & $1,288.9$ & 1.11 & 1.28 & $5,991.2$ & $6,673.6$ & 1.18 & 1.32 \\
\hline $\begin{array}{l}10000000- \\
50000000\end{array}$ & $2,340.1$ & $5,020.0$ & 1.02 & 1.15 & $18,577.0$ & $20,310.5$ & 1.14 & 1.25 \\
\hline 50000000- & $14,413.7$ & $30,598.1$ & 0.99 & 1.09 & $107,046.3$ & $118,971.7$ & 1.09 & 1.23 \\
\hline Total & 823.5 & $1,762.6$ & 1.29 & 1.52 & $6,572.9$ & $7,272.4$ & 1.47 & 1.59 \\
\hline
\end{tabular}

\section{Table 4}

\section{Correlation Coefficients}

This table presents the correlation coefficient matrix. 


\begin{tabular}{|c|l|l|l|l|l|l|l|l|l|}
\hline Variables & $(1)$ & $(2)$ & $(3)$ & $(4)$ & $(5)$ & $(6)$ & $(7)$ & $(8)$ & $(9)$ \\
\hline Debt/Assets (2010) & 1 & & & & & & & & \\
\hline Assets (2010) & -0.055 & 1 & & & & & & & \\
\hline TaxRate (2010) & -0.157 & -0.016 & 1 & & & & & & \\
\hline FARate (2010) & 0.451 & 0.028 & -0.005 & 1 & & & & & \\
\hline Cash (2010) & 0.017 & 0.802 & -0.032 & -0.055 & 1 & & & & \\
\hline EBIT (2011) & -0.081 & -0.017 & -0.072 & -0.019 & -0.013 & 1 & & & \\
\hline EBIT (11,12) & -0.077 & -0.016 & -0.064 & -0.013 & -0.011 & 0.958 & 1 & & \\
\hline Market Cap (2012) & 0.137 & -0.014 & 0.019 & -0.009 & -0.011 & -0.001 & 0.000 & 1 & \\
\hline Market Cap (2013) & 0.164 & -0.031 & -0.035 & -0.034 & -0.025 & 0.006 & 0.008 & 0.561 & 1 \\
\hline
\end{tabular}

\section{Table 5}

\section{Regression Results of Capital Structure}

The dependent variable is the Debt/Assets (2010) ratio. *** indicates significance at $1 \%$ level, ${ }^{* *}$ indicates significance at $5 \%$ level, and $*$ indicates significance at $10 \%$ level. 


\begin{tabular}{|c|c|c|c|c|c|}
\hline Variables & $(1)$ & $(2)$ & $(3)$ & $(4)$ & (5) \\
\hline Intercept & $\begin{array}{l}0.074 \\
{[2.90]^{* * *}}\end{array}$ & $\begin{array}{l}0.087 \\
{[3.12]^{* * *}}\end{array}$ & $\begin{array}{l}0.167 \\
{[8.77]^{* * *}}\end{array}$ & $\begin{array}{l}0.218 \\
{[9.21]^{* * *}}\end{array}$ & $\begin{array}{l}0.034 \\
{[1.67]^{*}}\end{array}$ \\
\hline Assets (2010) & $\begin{array}{l}-0.000 \\
{[-1.7]^{*}}\end{array}$ & $\begin{array}{l}-0.000 \\
{[-1.8]^{*}}\end{array}$ & $-0.000[-1.0]$ & & \\
\hline TaxRate (2010) & $\begin{array}{l}-0.1250 \\
{[-2.30]^{* *}}\end{array}$ & $\begin{array}{l}-0.1230 \\
{[-2.30]^{* *}}\end{array}$ & & $\begin{array}{l}-0.2170 \\
{[-3.70]^{* * *}}\end{array}$ & \\
\hline FARate (2010) & $\begin{array}{l}0.353 \\
{[10.66]^{* * *}}\end{array}$ & $\begin{array}{l}0.350 \\
{[10.46]^{* * *}}\end{array}$ & & & $\begin{array}{l}0.351 \\
{[11.07]^{* * *}}\end{array}$ \\
\hline Cash (2010) & $0.000[0.87]$ & $0.000[0.92]$ & & & \\
\hline EBIT (2011) & & $\begin{array}{l}-0.007 \\
{[-1.5]^{*}}\end{array}$ & & & \\
\hline EBIT $(2011,12)$ & $\begin{array}{l}-0.002 \\
{[-1.4]^{*}}\end{array}$ & & $\begin{array}{l}-0.003 \\
{[-1.8]^{*}}\end{array}$ & $\begin{array}{l}-0.0040 \\
{[-1.90]^{* *}}\end{array}$ & $\begin{array}{l}-0.002 \\
{[-1.2]^{*}}\end{array}$ \\
\hline MarketCap (2012) & & $\begin{array}{l}0.038 \\
{[3.08]^{* *}}\end{array}$ & & & \\
\hline MarketCap (2013) & $\begin{array}{l}0.038 \\
{[4.06]^{* * *}}\end{array}$ & & $\begin{array}{l}0.038 \\
{[3.55]^{* * *}}\end{array}$ & $\begin{array}{l}0.039 \\
{[3.77]^{* * *}}\end{array}$ & $\begin{array}{l}0.039 \\
{[4.13]^{* * *}}\end{array}$ \\
\hline Adj. $R^{2}$ & 0.241 & 0.230 & 0.029 & 0.054 & 0.229 \\
\hline F-value & 26.014 & 24.522 & 5.708 & 10.002 & 47.620 \\
\hline
\end{tabular}




\begin{tabular}{|c|c|c|c|c|}
\hline (6) & $(7)$ & $(8)$ & (9) & $(10)$ \\
\hline $\begin{array}{l}0.168 \\
{[8.97]^{* * *}}\end{array}$ & $\begin{array}{l}0.175 \\
{[8.04]^{* * *}}\end{array}$ & $\begin{array}{l}0.227 \\
{[8.68]^{* * *}}\end{array}$ & $\begin{array}{l}0.044 \\
{[1.99]^{* * *}}\end{array}$ & $\begin{array}{l}0.176 \\
{[8.19]^{* * *}}\end{array}$ \\
\hline \multirow{3}{*}[8.97]{$^{* * *}$} & $-0.000[-1.1]$ & & & \\
\hline & & $\begin{array}{l}-0.2170 \\
{[-3.70]^{* * *}}\end{array}$ & & \\
\hline & & & $\begin{array}{l}0.348 \\
{[10.86]^{* * *}}\end{array}$ & \\
\hline \multirow[t]{2}{*}{$\begin{array}{l}-0.000 \\
{[-1.7]^{*}}\end{array}$} & & & & $\begin{array}{l}-0.000 \\
{[-1.8]^{*}}\end{array}$ \\
\hline & $\begin{array}{l}-0.0100 \\
{[-1.90]^{* *}}\end{array}$ & $\begin{array}{l}-0.0110 \\
{[-2.20]^{* *}}\end{array}$ & $\begin{array}{l}-0.006 \\
{[-1.2]^{*}} \\
\end{array}$ & $\begin{array}{l}-0.0100 \\
{[-1.90]^{* *}}\end{array}$ \\
\hline \multirow[t]{2}{*}{$\begin{array}{l}-0.003 \\
{[-1.7]^{*}} \\
\end{array}$} & & & & \\
\hline & $\begin{array}{l}0.041 \\
{[3.03]^{* * *}}\end{array}$ & $\begin{array}{l}0.043 \\
{[3.17]^{* * *}}\end{array}$ & $\begin{array}{l}0.039 \\
{[3.18]^{* * *}}\end{array}$ & $\begin{array}{l}0.041 \\
{[3.02]^{* * *}}\end{array}$ \\
\hline \multicolumn{5}{|l|}{$\begin{array}{l}0.038 \\
{[3.56]^{* * *}}\end{array}$} \\
\hline 0.033 & 0.023 & 0.047 & 0.007298926 & 0.027 \\
\hline 6.368 & 4.666 & 8.803 & 5.970352551 & 5.290 \\
\hline
\end{tabular}

\section{Conclusions}

This paper examines optimal financing in a dynamic setting (two-stage investment process) under asymmetric information. The analysis is based on the idea that firms have private information about the timing of earnings. It 
is shown that separating equilibria may exist where firms issuing equity have higher performance in the first period and lower performance in the second period than firms issuing debt. The paper contributes to POT by explaining why firms can issue equity as a signal. It contributes to signalling theory by explaining why debt does not necessarily signal a firm's quality. The paper suggests that the debt-equity ratio is negatively correlated with short-term earnings and positively correlated with long-term earnings. It also provides new insights on important capital structure phenomena, such as the negative correlation between debt and profitability. To our knowledge, this is the first attempt to simultaneously explain all of these phenomena. Finally, this paper provides some new theoretical results that have not yet been tested. These are: 1) the decision about the issuance of standard securities, such as debt and equity, can be affected by the private information about the timing of earnings; 2) firms issuing equity have higher performance shortly after the issue; and 3) up-front financing is less likely (stage financing is more likely) when the moral hazard problem is important.

\section{Appendix 1}

The second-period incentive constraint (IC) is

$$
\alpha_{2} E \max \left\{m_{2}+r_{2}-D, 0\right\} \geq c+\alpha_{2} E\left\{m_{2}-D, 0\right\}
$$

where $D$ denotes the total face value of debt in the second period. The left side of (11) shows the entrepreneur's expected payoff if $e_{2}=1$ and the right side shows his payoff if $e_{2}=0$. If $D>0$ then $m_{2}=0$ and (11) can be rewritten as

$$
\alpha_{2} E \max \left\{r_{2}-D, 0\right\} \geq c
$$

If $D=0$ then (11) becomes: $\alpha_{2} E\left(m_{2}+r_{2}\right) \geq c+\alpha_{2} E m_{2}$ which also corresponds to (12). Note that the left side of (12) depends on the first-period dividend 
policy. If first-period dividends are high, the firm will borrow more in the second period and the IC will be stronger. The entrepreneur's optimal decision is to invest as much as possible, using internal financing, given that both investment in the second period and a high level of effort are socially optimal by 2 .

If the second-period IC holds and the entrepreneur provides a high level of effort in the first period, the entrepreneur's expected payoff equals the firstbest firm value which is equal to $1-2 b$. Therefore, the first-period IC is

$$
1-2 b \geq c+E\left[\alpha_{1} W_{1}+\alpha_{2} W_{2} \mid e_{1}=0\right]
$$

Under strategy $u$ the firm is always able to finance the second stage of the project internally. Thus, $D=0$ in 12 and the second-period IC is:

$$
\alpha_{2} E r_{2} \geq c
$$

Given that $r_{1}=W_{1}=0$ when the first-period level of effort is low, we can rewrite (13) as

$$
1-2 b \geq c+\alpha_{2} E r_{2}
$$

As follows from the proof of Proposition $1, \alpha_{1}=\alpha_{2}=1-2 b$ and we can rewrite (14) and 15 as:

$$
\begin{gathered}
(1-2 b) \theta \geq c \\
(1-2 b)(1-\theta) \geq c
\end{gathered}
$$

If a firm has a growing earnings profile, the consequences of entrepreneurial moral hazard are less pronounced in the first period because the expected profit from a high level of effort is relatively low, and visa versa for the other type. 
Formally, if $\theta \leq 1 / 2$ the first condition is stronger ${ }^{16}$ On the other hand if $\theta>1 / 2$ the second condition is stronger. Hence we have: $u$ is optimal if and only if

$$
\theta \leq 1 / 2 \text { and } 16 \text { or } \theta>1 / 2 \text { and (17) }
$$

\section{Appendix 2}

If $\theta_{s} \leq 1 / 2$ then from (18) $u$ is the first-best strategy for each type when $c<(1-2 b) \theta_{j}, j=l, s$. Proposition 2 follows from $\theta_{s}>\theta_{l}$. If $\theta_{l}>1 / 2$ then, from (18) $u$ is the first-best strategy for both types if $c<(1-2 b)\left(1-\theta_{j}\right), j=$ $l, s$. Again, Proposition 2 follows from $\theta_{s}>\theta_{l}$. Now consider $\theta_{s}>1 / 2 \geq \theta_{l}$. From (18) $u$ is feasible for both types if $c<(1-2 b)\left(1-\theta_{s}\right)$ and $c<(1-2 b) \theta_{l}$. Note that in all cases, the off-equilibrium beliefs supporting these equilibria can be the same as those described in the previous proposition.

\section{Appendix 3}

Suppose the opposite is true, such that an equilibrium exists where $l$ plays $u$. First-period IC is

$$
c<(1-2 b) \theta_{l}
$$

From (5)-(7) this is only possible when $\theta_{l}>1 / 2$ or $\theta_{l}<1 / 2<\theta_{s}$ and

$$
c>(1-2 b)\left(1-\theta_{s}\right)
$$

The latter implies that if $s$ mimics $l$ and cheats (provides a low level of effort) in the second period, its total payoff is $(1-2 b) \theta_{s}+c$ and this is greater than $1-2 b$ by (19). Thus $s$ will mimic $l$ and such an equilibrium does not exist. The proof is analogous for the case when $s$ plays $u$.

\section{Appendix 4}

\footnotetext{
${ }^{16}$ Obviously, if $\theta=1 / 2$ the conditions are equivalent.
} 
Denote the total amount of funds raised in the first period by $b_{1}, b_{1} \in$ $\{b, 2 b\}$, the number of shares issued by $\Delta n$, the dividend per share in period $t$ by $w_{t}$, total dividend in period $t$ by $W_{t}$, and cash retained in period $t$ (analogous to being invested in zero coupon bonds) by $m_{t}$. The equilibrium relationships are:

1) first-period total investment equals first-period total financing:

$$
\begin{gathered}
b_{1}=p \Delta n \\
b_{1}=b+m_{1}
\end{gathered}
$$

2) market valuation of shares (share price equals expected dividends per share):

$$
p=E\left(w_{1}+w_{2}\right)
$$

3) total dividend in period $t$ :

$$
\begin{aligned}
& W_{1}=w_{1}(n+\Delta n) \\
& W_{2}=w_{2}(n+\Delta n)
\end{aligned}
$$

4) earnings in period $t$ :

$$
\begin{gathered}
r_{1}+m_{1}=W_{1}+f+m_{2} \\
\max \left\{m_{2}+r_{2}-D_{2}, 0\right\}=W_{2}
\end{gathered}
$$

First-period earnings (the sum of cash or investment in zero-coupon bonds in period 1 and cash flow from the project) can be used to pay out dividends, finance the second stage of the project, or invest in zero-coupon bonds in 
period 2. On the other hand, second-period earnings are distributed, in total, to the shareholders.

5) market valuation of second-period debt (recall that the firm raises $b-f$ externally in the second period).

$$
b-f=E \min \left\{m_{2}+r_{2}, D_{2}\right\}
$$

Using equations $(21),(23),(24),(25),(26), 27)$ and the identity

$$
\min (X, Y)+\max (0, X-Y)=X
$$

with $X=m_{2}+r_{2}$ and $Y=D_{2}$, we can transform (22) into:

$$
p=\frac{E r_{1}+E r_{2}-2 b+b_{1}}{n+\Delta n}
$$

This equation together with 20 produces

$$
p=\frac{1-2 b}{n}
$$

For second-period debt, we get from (27) that:

$$
D_{2}=\frac{b-f}{1-\theta}
$$

\section{Appendix 5}

Consider $V_{e}\left(\theta_{l}, \theta_{s}\right)$. From Lemma $2, p=\frac{1-2 b}{n}$ and therefore $\alpha_{1}=\frac{n}{n+b / p}=$ $\frac{1-2 b}{1-b}$.

\footnotetext{
${ }^{17}$ Further, we assume for brevity that $D_{2}>0$ which implies $m_{2}=0$. Note that no results are affected by this assumption. To see this, suppose that $D_{2}>0$ and $0<m_{2}<b-f$. Then $D_{2}=\frac{b-f-\theta m_{2}}{1-\theta}$. The entrepreneur's second-period expected payoff is $V_{2}=(1-\theta)(1+$ $\left.m_{2}-\frac{b-f-\theta m_{2}}{1-\theta}\right)=1-\theta-b+f+m_{2}$. Now suppose that the entrepreneur invests $m_{2}$ in the second stage of the project. Then $D_{2}=\frac{b-f-m_{2}}{1-\theta}$ and the entrepreneur's expected payoff equals $V_{2}^{\prime}=(1-\theta)\left(1-\frac{b-f-m_{2}}{1-\theta}\right)=1-\theta-b+f+m_{2}=V_{2}$. The idea is analogous for the case when $m_{2}>b-f$.
} 
Recall that $l$ finances internally if $r_{1}=1$. Thus

$$
V_{e}\left(\theta_{l}, \theta_{s}\right)=\frac{1-2 b}{1-b}\left(\theta_{l}\left(1-b+1-\theta_{l}\right)+\left(1-\theta_{l}\right)^{2}\left(1-\frac{b}{1-\theta_{s}}\right)\right)
$$

Lemma 3 follows from $\theta_{l}<\theta_{s}$ and (31). The proof is analogous for $V_{e}\left(\theta_{s}, \theta_{l}\right)$.

\section{Appendix 6}

Lemma 1A. When information between the firm and the market is symmetric, the debt face value equals: $L=\frac{2 b}{1-\theta+\theta^{2}}$ if $b \leq \frac{1-\theta+\theta^{2}}{2}$ and $L=$ $\frac{2 b-\theta^{2}+(1-\theta)^{2}}{\theta(1-\theta)}$ if $b>\frac{1-\theta+\theta^{2}}{2}$.

Proof. $L$ is determined by the following equation:

$$
2 b=E \min \left\{m_{2}+r_{2}, L\right\}
$$

Recall that long-term debt is issued with dividend covenants. Therefore, the firm uses its initial resources to finance the second stage, and must invest first-period earnings in zero-coupon bonds. We can thus rewrite (32) as:

$$
2 b=E \min \{r, L\}
$$

where $r$ denotes the firm's total cash flow over the two periods. Note that $r$ equals 2 with probability $\theta(1-\theta)$, equals 1 with probability $\theta^{2}+(1-\theta)^{2}$ and 0 otherwise. Two cases are possible. If $L \leq 1$ the probability that the creditors get the face value equals the probability that $r_{1}+r_{2} \geq 1$. Otherwise they get nothing. Thus:

$$
2 b=\left(1-\theta+\theta^{2}\right) L
$$

If $L>1$, we have

$$
2 b=\theta(1-\theta) L+\theta^{2}+(1-\theta)^{2}
$$

Let $L(\theta)$ denote the perfect information face value of long-term debt if the firm is of type $\theta$, assuming that $k$ is a first-best strategy for $\theta$ under symmetric 
information (it would invest in both periods and provide a high level of effort in both periods).

Lemma 2A. $L\left(\theta_{s}\right)>L\left(\theta_{l}\right)$ if $\theta_{s}+\theta_{l}<1, L\left(\theta_{s}\right)=L\left(\theta_{l}\right)$ if $\theta_{s}+\theta_{l}=1$, and $L\left(\theta_{s}\right)<L\left(\theta_{l}\right)$ if $\theta_{s}+\theta_{l}>1$.

Proof. $L\left(\theta_{s}\right)$ and $L\left(\theta_{l}\right)$ are both less than 1 . Otherwise, a high level of effort will not be provided in the second stage when $r_{1}=0$. Thus, Lemma 5 follows directly from (33). End proof.

Corollary 1A. 1) $V_{k}\left(\theta_{s}, \theta_{l}\right)>1-2 b$ if $\theta_{s}+\theta_{l}<1, V_{k}\left(\theta_{s}, \theta_{l}\right)=1-2 b$ if $\theta_{s}+\theta_{l}=1$, and $V_{k}\left(\theta_{s}, \theta_{l}\right)<1-2 b$ if $\theta_{s}+\theta_{l}>1$; 2) $V_{k}\left(\theta_{l}, \theta_{s}\right)>1-2 b$ if $\theta_{s}+\theta_{l}>1, V_{k}\left(\theta_{l}, \theta_{s}\right)=1-2 b$ if $\theta_{s}+\theta_{l}=1$, and $V_{k}\left(\theta_{l}, \theta_{s}\right)<1-2 b$ if $\theta_{s}+\theta_{l}<1$.

Proof. Suppose $\theta_{s}+\theta_{l}<1$ and consider $V_{l}(\theta, \widehat{\theta})$. This is equal to:

$$
V_{l}\left(\theta_{s}, \theta_{l}\right)=\theta_{s}\left(1-\theta_{s}\right)\left(2-L\left(\theta_{l}\right)\right)+\left(\theta_{s}^{2}+\left(1-\theta_{s}\right)^{2}\right)\left(1-L\left(\theta_{l}\right)\right)
$$

By Lemma 5

$V_{l}\left(\theta_{s}, \theta_{l}\right)>\theta_{s}\left(1-\theta_{s}\right)\left(2-L\left(\theta_{s}\right)\right)+\left(\theta_{s}^{2}+\left(1-\theta_{s}\right)^{2}\right)\left(1-L\left(\theta_{s}\right)\right)=V_{l}\left(\theta_{s}, \theta_{s}\right)=1-2 b$ This proves the first part of the corollary. The proof is analogous for the second part. End proof.

Proof of Proposition 4. Consider a separating equilibrium where $l$ plays $k$ and $s$ plays $e$. Then from $(33) L=\frac{2 b}{1-\theta_{l}+\theta_{l}^{2}}$. Suppose that $\theta_{l}+\theta_{s}<1$. In this case $s$ will mimic $l$ by Corollary 2. Thus:

$$
\theta_{l}+\theta_{s}>1
$$


which implies $\theta_{s}>1 / 2$. From (5), (6) and (35) we get $c>(1-2 b)\left(1-\theta_{s}\right)$. Now consider the IC of type $s$ in the second period. As was mentioned previously, $\alpha_{1}=\frac{1-2 b}{1-b}$. Type $s$ earns $1-\theta_{s}-b$ in the second period. Hence, the entrepreneur will provide a high effort only if $c<\frac{(1-2 b)\left(1-\theta_{s}-b\right)}{1-b}$. However, this contradicts the condition $c>(1-2 b)\left(1-\theta_{s}\right)$. End proof.

\section{Appendix 7}

Denote the face value of first-period debt by $D_{1}$. We have the following relationship:

$$
b=E \min \left\{r_{1}, D_{1}\right\}+\operatorname{Pr}\left(r_{1}<D_{1}\right) \lambda E W_{2}
$$

Equation (36) takes into account the fact that creditors receive a fraction $\lambda$ of equity when first-period cash flow is insufficient to pay off short-term debt. This equation can be rewritten as

$$
b=\theta D_{1}-\lambda(1-\theta) E\left(W_{2} \mid r_{1}<D_{1}\right)
$$

If $r_{1}<D_{1}$ (default), $f=m_{2}=0$. Using (26), (27) and (28) with $X=r_{2}$ and $Y=D_{2}$ we get:

$$
E\left(W_{2} \mid r_{1}<D_{1}\right)=1-\theta-b
$$

(37) and 38 imply

$$
D_{1}=\frac{b-\lambda(1-\theta)(1-\theta-b)}{\theta}
$$

\section{Appendix 8}

Other separating equilibria with debt and equity.

From Corollary 1, we know that the debt/equity ratio is negatively correlated with short-term performance and positively correlated with long-term 
performance. The problem with our analysis thus far is that we have not considered an inefficient separating equilibrium. The general intuition regarding this equilibrium is as follows. If both types invest only in the first stage of the project and provide high effort in that period (the issued claims will obviously depend only on the first-period expected performance), $l$ will mimic $s$ (recall that $s$ is the low profit type in this period). A situation where a firm only invests in the second stage is impossible because the stages are technologically dependant. Thus, at least one type will invest in both stages, provide high effort in the first period, and provide high effort in the second period when $r_{1}=1$ (and possibly when $r_{1}=0$ ). Otherwise, the investors will be unable to provide financing for both periods because cash from only one period is insufficient to cover the total investment, by (1). In equilibrium, $l$ is unable to use strategy $e$ and invest in both stages since it will be mimicked by $s$. This leads to the following proposition:

Proposition 1A. The only inefficient separating equilibria where both debt and equity are issued, are the following: 1) l plays $d$ and invests in both stages (high effort in both stages) and s plays e, invests in the first stage, and provides high effort in that stage; 2) l plays $z$ and invests in both stages (high effort in the first stage and also in the second stage when $\left.r_{1}=1\right)$ and $s$ plays e and invests only in the first stage; and 3) s plays $z$ and invests in both stages (high effort in the first stage, and also in the second stage when $\left.r_{1}=1\right)$ and $l$ plays $e$ and only invests in the first stage.

Proof. $l$ plays $e$ and $s$ plays $d$. If $l$ provides a high effort in both periods it will be mimicked by $s$ because of the "lemon" argument (Lemma 3). Consider the case when $l$ only obtains first-period financing (and provides a high effort in this period). We have:

$$
b=p \Delta n
$$




$$
p=\frac{\theta_{l}}{n+\Delta n}
$$

400 and 411) imply $p=\frac{\theta_{l}-b}{n}$ and $\alpha_{1}=\frac{\theta_{l}-b}{\theta_{l}}$. The equilibrium payoff of $l$ is obviously $\theta_{l}-b$. Suppose that $s$ provides a high effort in the first period. Then $D_{1}=\frac{b-\lambda\left(1-\theta_{s}\right)\left(1-\theta_{s}-b\right)}{\theta_{s}}$. If $l$ mimics $s$ it has at least $\theta_{l}\left(1-\frac{b}{\theta_{s}}\right)>\theta_{l}-b$. Thus, such a situation is impossible. Now if $s$ provides low effort in the first period and is subsequently liquidated, the entrepreneur gets $c$. The IC for $l$ is

$$
c<\theta_{l}-b
$$

If $s$ mimics $l$ it gets $\frac{\theta_{l}-b}{\theta_{l}} \theta_{s}>\theta_{l}-b>c$ (its equilibrium payoff). The latter inequality follows from (42). Thus such an equilibrium is impossible.

The cases where $l$ or $s$ provide low levels of effort in the first period and high levels of effort in the second period are impossible. The firm's total earnings are $1-\theta$, which is less than the total investment by (1). The last observation also holds for the situations considered below.

$l$ plays $e$ and $s$ plays $k$. Consider the case when $l$ only obtains first-period financing (and provides a high level of effort in this period). The situations where the level of effort of $s$ is high in the first period and low in the second (under both earnings realizations) and where its effort is low in the first period and high in the second are impossible by (1): the earnings from only one stage are not sufficient to cover the total cost of investment $(2 b)$. Now suppose that $s$ provides a high level of effort in both periods. The incentive constraint for $l$ is given by (42). If $\theta_{l}+\theta_{s}>1$, then $l$ mimics $s$ and gets a higher payoff than its equilibrium payoff by Corollary 1 . Consider $\theta_{l}+\theta_{s}<1$. It implies $\theta_{l}<1 / 2$. From (6) and (7) $c>(1-2 b) \theta_{l}$. The latter contradicts (42). The only possible case where $s$ provides high level of effort in both the first and second periods is when $r_{1}=1$. 
$l$ plays $k$ and $s$ plays $e$. The case when the effort of $l$ is high in the first period and low in the second, under both states, is impossible given the previous argument. Now consider the case when $l$ provides a high level of effort in both periods provided $r_{1}=1$. The payoff to $l$ equals $2 \theta_{l}-\theta_{l}^{2}-2 b+c\left(1-\theta_{l}\right)$. Suppose that $s$ exerts high effort in both periods. In this case, $l$ will mimic $s$. $\quad l$ will provide a high level of effort in the second period only if $r_{1}=1$, and will get $\frac{1-2 b}{1-b}\left(\theta_{l}\left(1-b+1-\theta_{l}\right)\right)+c\left(1-\theta_{l}\right)$. This is more than his payoff in equilibrium. Thus, $l$ will deviate. Finally, the only possible cases are those where $s$ obtains financing for the first period and provides a high level of effort in that period, and where $l$ provides a high level of effort in both periods provided that $r_{1}=1$.

$l$ plays $d$ and $s$ plays $e$. First consider the following case: $s$ provides a high level of effort in both periods and $l$ provides a high level of effort only in the first period. We have $p=\frac{1-2 b}{n}$. If $l$ mimics $s$ and provides a low level of effort in the second period it gets $\frac{1-2 b}{1-b} \theta_{l}+c$ which is more than its equilibrium payoff of $\theta_{l}-b$. Now consider the case when both types provide a high level of effort in the first period and a low level of effort in the second period. We have $p=\frac{\theta_{s}-b}{n}$. Hence, $l$ mimics $s$, and gets $\frac{\theta_{s}-b}{\theta_{s}} \theta_{l}>\theta_{l}-b$.

One can see from Proposition 6 that in any equilibrium, a firm issuing equity has smaller expected earnings in the second period than a firm issuing debt.

Finally, note that strategy $u$ does not play an important role. If $u$ is played in equilibrium then by (1) the effort should be high in both periods. However, such a situation is impossible given that (5)-(7) should hold (analogously to Proposition 3). End Proof. 


\section{References}

\section{References}

[1] Akerloff, G. (1970). The Market for Lemons: Quality Incertainty and the Market Mechanism. Quarterly Review of Economics, 74, 488-500.

[2] Brick, I., M. Frierman \& Y. K. Kim. (1998). Asymmetric Information Concerning the Variance of Cash Flows: The Capital Structure Choice. International Economic Review, 39, 745-761.

[3] Chichti, J., \& K. Bougatef. "Equity Mmarket Ttiming and Ccapital Sstructure: Evidence from Tunisia and France." Working paper. 2010. Available at http://www.tn.refer.org/CEAFE/Papiers_CEAFE10/Fina_marche/Bougatef.pdf.

[4] Daniel, K., \& S. Titman. "Financing Investment under Asymmetric Information". In R. Jarrow, V. Maksimovic and V. Ziemba. Handbooks In OR and MS, 9 (1995), Elseveir, 721-766.

[5] Giammarino, R. (1989). The Resolution of Financial Distress. Review of Financial Studies 2, 25-48.

[6] Giammarino, R., \& E. Neave. "The Failure of Financial Contracts and the Relevance of Financial Policy", Queen's University, School of Business, Working paper \#82-3, 1982.

[7] Goswami, G., T. Noe, \& M. Rebello. (1995). Debt Financing under Asymmetric Information. Journal of Finance, 50, 633-659.

[8] Hart, D. M., Making, Breaking, and (Partially) Remaking Markets: State Regulation and Photovoltaic Electricity in New Jersey (July 1, 2009). MIT IPC Working Paper 
No. 09-005; GMU School of Public Policy Research Paper No. 2009-06. Available at SSRN: https://ssrn.com/abstract $=1457201$

[9] Jain, B., \& Kini, O. (1994). The Post-Issue Operating Performance of IPO Firms. The Journal of Finance, 49, 1699-1726.

[10] Jensen, M., \& W. Meckling, W. (1976). Theory of the Firm: Managerial Behavior, Agency Costs and Ownership Structure. Journal of Financial Economics 3, 305-360.

[11] Klein, L., O'Brien, T., \& S. Peters. (2002). Debt vs. Equity and Asymmetric Information: A Review. The Financial Review 37, 317-349.

[12] Komera, S. \& P. J. Lukose. (2015). Capital structure choice, information asymmetry, and debt capacity: evidence from India. Journal of Economics and Finance, 39, 807823

[13] Leland, H. E., \& D. H. Pyle. (1977). Information Asymmetries, Financial Structure, and Financial Intermediation. Journal of Finance, 32, 371-378.

[14] Loughran, T., \& J. R. Ritter. (1997). The Operating Performance of Firms Conducting Seasoned Equity Offerings. Journal of Finance, 52, 1823-1850.

[15] Lucas, D. J. \& R. L. McDonald. (1990). Equity Issues and Stock Price Dynamics. Journal of Finance, 45, 1019-43.

[16] Mercer-Blackman, V., The Impact of Research and Development Tax Incentives on Colombia's Manufacturing Sector: What Difference Do They Make? (July 2008). IMF Working Papers, Vol. , pp. 1-53, 2008. Available at SSRN: https://ssrn.com/abstract $=1266511$

[17] Mickelson, W., Partch, M. \& Shah, K. (1997). Ownership and Operating Performance of Companies That Go Public. Journal of Financial Economics, 44, 281-307. 
[18] Miglo, A. (2007). Debt-equity choice as a signal of earnings profile over time. Quarterly Review of Economics and Finance, 47, 69-93.

[19] Miglo, A., (2011), Trade-off, Pecking Order, Signaling and Market Timing Models. In Baker, H. K., and G. S. Martin (Ed.) Capital Structure and Corporate Financing Decisions: Theory, Evidence, and Practice. Wiley, Ch. 10, 171-190.

[20] Miglo, A. (2012). Multi-stage investment, long-term asymmetric information and pecking-order theory revisited. Journal of Current Issues in Finance, Business and Economics, 4, 331-348.

[21] Miglo, A. Capital Structure in the Modern World. Springer-Palgrave-MacMillan, 2016. ISBN 978-3-319-30713-8.

[22] Miglo, A., \& N. Zenkevich. (2006). Non-hierarchical signalling: two-stage financing game. International Journal of Mathematics, Game Theory and Algebra, 15, 257-273.

[23] Mohamed, E., \& T. Eldomiaty. (2009). Is Debt Governance Structure Relevant to Firm Operating Performance in Egypt? A Dynamic Approach. International Journal of Accounting and Finance, 1, 216-249.

[24] Myers, S.C., \& Majluf, N.S. (1984). Corporate Financing and Investment Decisions When Firms Have Information That Investors Do not have. Journal of Financial Economics, 13, 187-221.

[25] Neher, D. (1999). Stage financing: an agency perspective. Review of Economic Studies, $66,255-274$.

[26] Pereira, T., \& M. Sousa. (2015). Is There Still a Berlin Wall in the Post- Issue Operating Performance of European IPOs? Available at SSRN: http://ssrn.com/abstract $=2347535$ 
[27] Ross, S. A. (1977). The Determination of Financial Structure: The Incentive Signaling Approach. Bell Journal of Economics, 8, 23-40. 